This is an Accepted Manuscript of an article published in Journal of Rural Studies, doi: https://doi.org/10.1016/j.jrurstud.2017.07.004.

\title{
The influence of village attractiveness on flows of movers in a declining rural region
}

Hans Elshof, Tialda Haartsen, Leo J.G.van Wissen, Clara H.Mulder

\section{Introduction}

The attractiveness of rural areas has often been described as the rural idyll. And indeed, research has shown that a desire for space, quiet, greenery, and safety can motivate people to move from urban to rural areas; a trend known as counterurbanisation (Champion 1989, Boyle et al. 1998). Despite having these attractive features, rural regions around the world are seeing their populations decline because of trends such as continuing urbanisation and below-replacement levels of fertility. However, the extent to which people are leaving particular places can vary within generally depopulating regions. Indeed, villages that are growing or declining can be located right next to each other (Bontje and Musterd 2012). However, the questions of how and why these differences between villages exist have hardly been studied.

The flows of movers to and from rural villages are unquestionably major causes of shifts in rural populations at the local level. Whereas flows into and out of rural areas have attracted much attention, research on people moving within rural regions is scarce. Milbourne (2007) found it "surprising that more has not been said about these more local migrations" (p. 385), because "different mobilities, present in different combinations in different places [...] produce the complexities of rural population change" (p.386). Especially in the context of population decline, these short-distance relocations can cause rural villages to thrive or shrivel demographically, because movers are likely to have more housing options to choose from in declining regions than in growing regions.

The lack of attention given to moves within rural regions has also been noted by Stockdale (2015). She pointed out that "these shorter steps are rarely studied" (para. Conclusion), even though her research showed that $41 \%$ of changes of address in rural areas were undertaken from within rural areas. Furthermore, Van der Molen (1993) observed that although the majority of older people within the Netherlands move within the same municipality, research has often overlooked these intra-local moves. Similarly, other studies conducted in rural North-Netherlands have shown that most moves occur between rural municipalities, while the numbers of rural-urban, urban-rural, and inter-urban moves are smaller (Bijker and Haartsen 2012); and that more than half of all movers either moved within their own village or moved within 10 kilometres of their previous address (Elshof et al. 2014).

People move to places with characteristics that best suit their interests; i.e., that are most attractive. What is considered attractive depends on the characteristics of a place, but also on the people who evaluate these characteristics (e.g., Argent et al. 2007, Argent et al. 2014, Bijker et al. 2012, Stockdale and Catney 2014). It is well known, for instance, that many young adults are attracted to cities that provide greater opportunities for education and employment (Champion 1999); whereas somewhat older middle-class families are often attracted to aspects of the rural idyll, such as peace and quiet 
(Halfacree 2008). Nonetheless, recent studies have shown that there is a wide range of motivations for people to migrate to rural areas (Grimsrud 2011, Halfacree 2008, Bijker et al. 2013).

Over the past few decades, the interest among scholars in the role of amenities in migration has been increasing (Niedomysl and Clark 2014). Referring to population change in rural villages, Argent et al. (2009) argued: "the nature, direction, and regional manifestations of population change are strongly related to the varying levels of local amenity" (p.15). The natural qualities of the living environment have often been considered to be amenities that influence moving behaviour. Halfopen landscapes (McGranahan 2008, Bijker et al. 2012), nearby beaches (Argent et al. 2007, McGranahan 1999), and other aspects of scenic beauty (Halfacree 1995, Ulrich 1986, Deller et al. 2001) have all been found to attract people. These characteristics are often associated with the rural idyll, as are social aspects such as friendly people, a less hurried lifestyle, and less crime (Cloke 2003, Gkartzios and Scott 2009, Short 2006, Van Dam et al. 2002). However, characteristics that are less related to the rural idyll have also been shown to motivate moves to rural areas, such as cheap housing and proximity to family and friends (Bijker 2012).

At the local level, it is likely that certain villages attract or repel people of different ages, because the needs of people change over the life course. For example, while some people are drawn to the remoteness of rural areas, others prefer to stay closer to metropolitan centres. Although the relationship between moving and age is well established, the geography of moving in this relationship is often ignored (Stockdale and Catney 2014). It is therefore important that we gain more insight into the question of how attractive rural villages are for people of different ages.

In this paper, we investigate flows of movers of different age categories to rural villages in a declining region. Although we also analyse inward and outward flows, our focus is on net settlement (the difference between inward and outward flows) because given the general decline in the population, it is net settlement that determines (together with natural growth) whether a village population will grow, stabilise, or decline. In this paper, we aim to show that whether a rural village is considered attractive depends on more factors than those of the rural idyll, but that the extent to which this is the case differs over age. We begin our study by exploring patterns of net settlement by age category in rural villages in order to provide some initial insights into how people of different ages move within rural areas, and how the populations of villages are affected. We then analyse which village characteristics influence the net settlement rates among different age categories in rural villages in North-Netherlands.

We used a cluster analysis to investigate the net settlement patterns of rural villages in NorthNetherlands among different age categories. Using linear regression, we analysed the influence of various village characteristics on inward and outward flows of movers of villages, and, consequently, on net settlement. We derived the data for the calculation of inward and outward flows and net settlement at the village level from the Dutch population register for the period 1995-2010. To get a more complete picture of which rural villages 'win' or 'lose' people, and of the reasons why, we included in our study both short-distance relocations and long-distance migration. The set of village characteristics that might account for the villages' levels of attractiveness were provided by Statistics Netherlands, the Netherlands' Cadastre Land Registry and Mapping Agency, the Ministry of Education, Culture and Heritage, and the Ministry of Economic Affairs. 


\section{The influence of attractiveness on flows of movers in rural villages}

The enduring lure of cities is one of the causes of population decline in rural areas. In the Netherlands, as in many other post-industrialised countries, young adults contribute heavily to the depopulation of rural areas by migrating to urban areas in search of educational and employment opportunities (Haartsen and Venhorst 2010, Thissen et al. 2010). Previously, this migration deficit was compensated for by high levels of fertility, but fertility levels in the Netherlands have been below replacement level for several decades (Statistics Netherlands 2016). As in many other countries, some young adults return, but many of them stay in or close to the cities to 'cash out' their investments in education, only to return to the countryside in later life (Fielding 1992), or not at all. In addition to these economic reasons, young people tend to move to the city because of its liveliness. "The city has more [...] 'action', [...] and, is to be preferred over the restricted and comparatively uneventful life of the village" (Brandes 2013).

Conversely, some people move from urban to rural areas. This process of counterurbanisation has been previously described as the influx of middle-class groups who are attracted by the rural idyll (Champion 1999, Halfacree 1995, Halfacree 2008). It has been posited that while movers to urban areas are searching for liveliness, these rural movers are seeking peace and quiet. However, more recent research has pointed out that migration to rural areas is also driven by other motivations, and that other groups of people are moving to the country. For example, young adults may move to rural areas because they are attracted by cheap housing, or because they want to be close to family and friends (Bijker et al. 2013, Grimsrud 2011, Haartsen and Thissen 2014, Stockdale 2006).

Moves within rural regions have received less attention from researchers than moves into and out of rural areas. Nonetheless, the importance of investigating these moves within rural regions has been highlighted by several researchers. Walford (2007) showed that in rural Wales, most people moved over short distances, and that certain places have enduring migration links. Stockdale (2015) encountered 'messy' in-migration processes in rural England, where counterurbanisation is still an important trend, but lateral rural, return, and retirement migration processes are also occurring. Another study by Bijker et al. (2012) made a distinction between popular and less popular rural areas in North-Netherlands based on housing value. They found that less popular areas have a higher influx of movers from other rural areas, whereas migration into popular areas is more indicative of the classical counterurbanisation trends among middle-class people who move from urban areas in search of the rural idyll. Research investigating the influence of village characteristics on the flows of movers at this low-scale level is nevertheless lacking.

It is generally expected that flows of movers into and out of rural villages will be influenced by the attractiveness of the village; i.e., that the influx of people will be higher and the outflow will be lower in villages that are considered to be more attractive. There is, however, no clear consensus on which features contribute to or detract from the attractiveness of a village. While all rural villages offer space and quiet, certain village characteristics may contribute more to the idyllic character of the village than others. Furthermore, as age and life course stage are important predictors of personal preferences and of moving behaviour (e.g., Rossi 1955, Courgeau 1985, Stockdale and Catney 2014), these characteristics should be taken into account in discussions on how amenities and the flows of movers are related.

\subsection{The amenity of scenic beauty and flows of movers}

The term 'amenities' refers to the features that enhance the quality of a living environment. Partridge (2010) defined amenities as: "simply anything that shifts the household willingness to locate in a particular location. By definition, they are broadly defined and include weather, landscape, public services, public infrastructure, crime, ambience, and so on..." (p. 518). 
The scenic beauty of an area clearly adds to the image of the rural idyll, and consists of both natural features and human-made constructions. One natural feature that is often used to judge the attractiveness of a landscape is the degree of openness. At the one extreme there are the open landscapes that are found in agricultural areas, while at the other extreme there are the closed landscapes that are full of trees. Research has shown that both extremes are considered to be less attractive than half-open landscapes with alternating patches of farmland and forest (McGranahan 2008, Argent et al. 2009). The landscapes in North-Netherlands generally have one of three soil types: marine clay, former peat, and sand. In general, places with clay and peat soil can be characterised as open landscapes suited for agriculture, but not very idyllic. Sandy areas appear to be more idyllic; they contain more trees, but no large forests, and are perceived as being the most attractive areas in North-Netherlands (Haartsen and Strijker 2010).

The presence of bodies of water has also been found to be an amenity of scenic beauty. Research in the US (McGranahan 1999) and in Australia (Argent et al. 2007) has found that places closer to the sea attract more people than places that are located inland. Oceans and other bodies of water provide recreational opportunities, like walking along the beach, swimming, and fishing. The Waddensea, which borders the northern part of North-Netherlands, is an intertidal zone with many mud flats, but no beaches. It is, however, a protected natural area, which also offers recreational opportunities. A study by Van Dam et al. (2002) found that almost one-half of the people who recently moved to places located close to selected protected natural areas in North-Netherlands were motivated by the physical characteristics of this living environment. These areas also had an above-average influx of early retirees and older people.

Scenic beauty can also be found in the built environment. Historical architecture, such as smaller historical farmhouses (Barr 2002), are often considered more beautiful than present-day architecture (Brueckner 1999). In some North-Netherlands villages, a large share of the housing was built in the late $19^{\text {th }}$ century or in the first half of the 20th century. During this period, rich farmers not only built large and extravagant houses on their farmsteads, but also visually attractive houses in nearby villages (so-called rentenierswoningen) that they moved into when they retired. In contrast, houses that were built during the period of reconstruction after World War II are of lower construction and aesthetic quality, and are now considered to be less attractive (Verwest et al. 2008).

\subsection{Other amenities and flows of movers}

Other village characteristics can also be classified as amenities, but do not add specifically to scenic beauty. People may, for instance, be inclined to live close to specific services (Dustman and Okatenko 2014), such as primary schools or supermarkets. Services often fulfil practical needs, but as their presence can make life easier, they may contribute to the attractiveness of a village. Especially in the context of population decline, in which government budgets are decreasing and services are disappearing, services may be seen as valued amenities. The existing research on the impact of local services on flows of movers is limited. There are, however, studies that have looked at the question of whether the presence of a primary school influences flows of movers. We would expect to find that families with children are more likely to move to villages that have a primary school. Thus far, however, research has shown that the effect of the presence of a primary school on moving is limited (Amcoff 2012, Barakat 2015, Elshof 2015b).

Among the other services that could be considered amenities and that might influence migration are health services. In particular, older people might be inclined to live close to a general practitioner or a hospital because they have a greater need for health care and are less mobile than younger people. Older people might also value living close to a supermarket more than younger people. In addition to making it easier for them to buy groceries, a village supermarket can provide older people with a reason to go outside and socialise (Gardner 2011). 
The influence of the availability of recreational services on the decision to move, such as hotels and restaurants, can be viewed from a direct as well as an indirect perspective. Recreational services can be seen as directly contributing to the attractiveness of a place by providing leisure activities and employment opportunities. From an indirect perspective, recreational services can be seen as a proxy of attractiveness because they are often located in areas that have other features that are of interest to people, such as restaurants with lake views or hotels located close to public transportation. Johnson and Beale (1994) found that populations in centres of recreation with relatively high numbers of recreational services grew faster than populations in other places. Smailes et al. (2005), Argent et al. (2007), and Bijker et al. (2012) also found that places where the proportion of the population employed in the recreational sector was relatively high attracted more migrants.

Relative isolation is a feature of the rural idyll (Halfacree 1995). Nevertheless, most people in rural areas prefer to live close to a metropolitan centre rather than in a remote place (Argent et al. 2009). Rural villages close to metropolitan and urban centres have higher levels of population growth than more remote places (Bollman and Briggs 1992, Johnson and Beale 1994, Westlund 2002). Living in a village close to an urban area gives people the opportunity to enjoy the attractive features of both rural and urban places. Research conducted in North-Netherlands showed that the popular and the less popular municipalities (based on housing value) did not differ in terms of their distance to the nearest urban centre. However, the popular municipalities were located closer to the economic centres in West- and Central-Netherlands (Bijker et al. 2012).

Whether a place is considered to be remote also depends on its access to transportation infrastructure. Gkartzios and Scott (2009) found for Ireland that rural places that were more connected to main roads and railways had higher growth rates than places that were less connected. It may be expected that being close to public transportation infrastructure is especially important for people who travel frequently; i.e., people of working age. However, as households in this age category in rural areas also often have at least two cars, they may not need to have access to public transportation. Meanwhile, older people may travel less than working-aged people, but they may be more dependent on public transportation to get around, as car ownership levels are lower in this age category (Tacken 1998).

\subsection{Jobs and other village characteristics}

One of Ravenstein's 11 "laws of migration" from 1876 states that "the major causes of migration are economic" (in: Boyle et al. 1998, p. 60). Although it has since been shown that people migrate for many different reasons, it also appears that in many places specific categories of people are especially likely to move for economic reasons (Boyle et al. 1998). For example, within the Netherlands many people move from North-Netherlands, where there are relatively few jobs, to the economic centres in West- and Central-Netherlands, where there are more jobs with higher pay (Rees 1998).

Because many people now commute to work, employment opportunities in villages are less valued by residents than they were in the past. Rural villages have gone from being autonomous places where where people both live and work to being residential communities where people reside while working elsewhere (Thissen and Loopmans 2013). As there are relatively few employment opportunities in most villages, it is important to village residents that they can commute to a workplace that is a reasonable distance away. As Van Ham (2002) has explained, villages that are located between cities are within commuting distance of most jobs, and can thus be seen as more attractive than remotely located villages.

Other village characteristics might also influence the decision to move to a rural village. It is generally expected that the larger the village is, the smaller the flows into and out of the village will be. This is 
because residents of a larger village who want to move are more likely to find available housing in their current village than residents of a smaller village. Additionally, larger villages tend to have more services than smaller villages. This is also the case in villages with a higher population density (Kim et al. 2005). Larger and more densely populated villages are therefore expected to be more attractive to older people, who generally prefer living close to services (Van der Molen 1993). Moreover, homes for the elderly are more likely to be situated in larger villages (Van der Molen 1993).

New housing construction in a village is also expected to attract new inhabitants. This is plausible even in a context of population decline and an oversupply of housing, because the housing that is vacated in such situations is often poorly maintained and in the lowest segment of the market, and is therefore not seen as a serious option by many movers (Verwest et al. 2008). Furthermore, home owners move less frequently than renters (Clark and Dieleman 1996, Dieleman 2001, Helderman et al. 2004), because home ownership involves long-term commitments such as having a mortgage. It may thus be expected that in villages where a large share of the housing is owner-occupied the mobility rates are relatively low. Because buying a house requires a financial commitment, it may be expected that young adults, who often cannot afford such a commitment, are less likely to move to villages where a large share of the housing is owner-occupied. Many studies have also shown that housing prices are higher in amenity-rich areas (e.g., Can 1992, Polinsky and Rubinfeld 2013). As young adults are less likely than older adults to be able to afford expensive housing, it may be expected that they will be less likely to move to villages with higher amenity levels. This hypothesis is supported by a study from Bijker et al. (2012), who found that in North-Netherlands young people move less frequently than older people to relatively expensive rural areas. 


\section{Data and methods}

\subsection{The study area}

North-Netherlands is a region of the Netherlands that includes three provinces: Groningen, Friesland, and Drenthe. It is considered the most rural region in the Netherlands based on its relatively low population density (Haartsen et al. 2003). The economy has traditionally relied on agriculture and industry, but the service industry is also well developed in the urban areas. For example, the city of Groningen, with around 200,000 inhabitants, hosts a university. Just over 1.7 million people lived in North-Netherlands in 2010 , or about 100,000 people more than in 1995 . Nevertheless, many rural areas of the region have faced population decline, and especially the more peripheral areas in the north and east (Haartsen and Venhorst 2010). Only six municipalities in the region had more than 50,000 inhabitants, according to recent figures (Statistics Netherlands 2015). About $65 \%$ of the inhabitants of North-Netherlands were living in rural areas (fewer than 1000 addresses per square kilometre) in 2011 , compared with just $38 \%$ of the total population of the Netherlands (Statistics Netherlands 2016).

Rural North-Netherlands can roughly be divided in three types of areas based on the dominant soil. In the north, closer to the Waddensea, there are areas of marine clay with open agricultural landscapes and dykes. Some of the villages in these areas were founded around a road, are stretched out, and have relatively low address densities. Other villages were founded on dwelling mounds (called terpen in Friesland or wierden in Groningen). These villages tend to have a street plan that follows a radial pattern, a higher address density, and more old buildings. The rest of NorthNetherlands consists of sandy and former peat areas. Most of the villages located in sandy areas are older and more compact, and thus have higher address densities. The surrounding areas are often sloping and contain patches of forests. The villages in former peat areas are constructed around canals or roads, are more stretched out, and therefore have lower address densities. These villages are generally not as old as the villages in sandy areas and are set in a flat landscape suited for agriculture.

\subsection{Village selection}

To analyse the flows of movers in rural villages, we used the neighbourhood classification system of Statistics Netherlands: i.e., a neighbourhood is defined as a part of a municipality with homogenous socio-economic structures (Statistics Netherlands 2015). Larger cities and towns are often divided into several neighbourhoods, whereas rural villages in general form a single neighbourhood. Other neighbourhood areas are determined by their agricultural, industrial, or recreational functions and often comprise large areas relative to the size of their population. Because this research focuses on rural villages, a selection of neighbourhoods in North-Netherlands was included in this study (see figure 1). Excluded from the study were (1) urban neighbourhoods with an address density of more than 1000 addresses per square kilometre; (2) neighbourhoods with an agricultural, industrial, or recreational rather than a residential function; (3) neighbourhoods on the Wadden islands, because it may be expected that the unique setting of these neighbourhoods creates a different dynamic; (4) all neighbourhoods with fewer than 50 inhabitants because of their limited size; (5) neighbourhoods with an asylum seekers centre, because forced moves may cause growth rates to be too volatile; and (6) neighbourhoods with migration rates per age category that differed by $+/-3$ standard deviations from the average migration rate, and were thus outliers. All other neighbourhoods were included in the village selection.

Figure 1: Selected neighbourhoods 


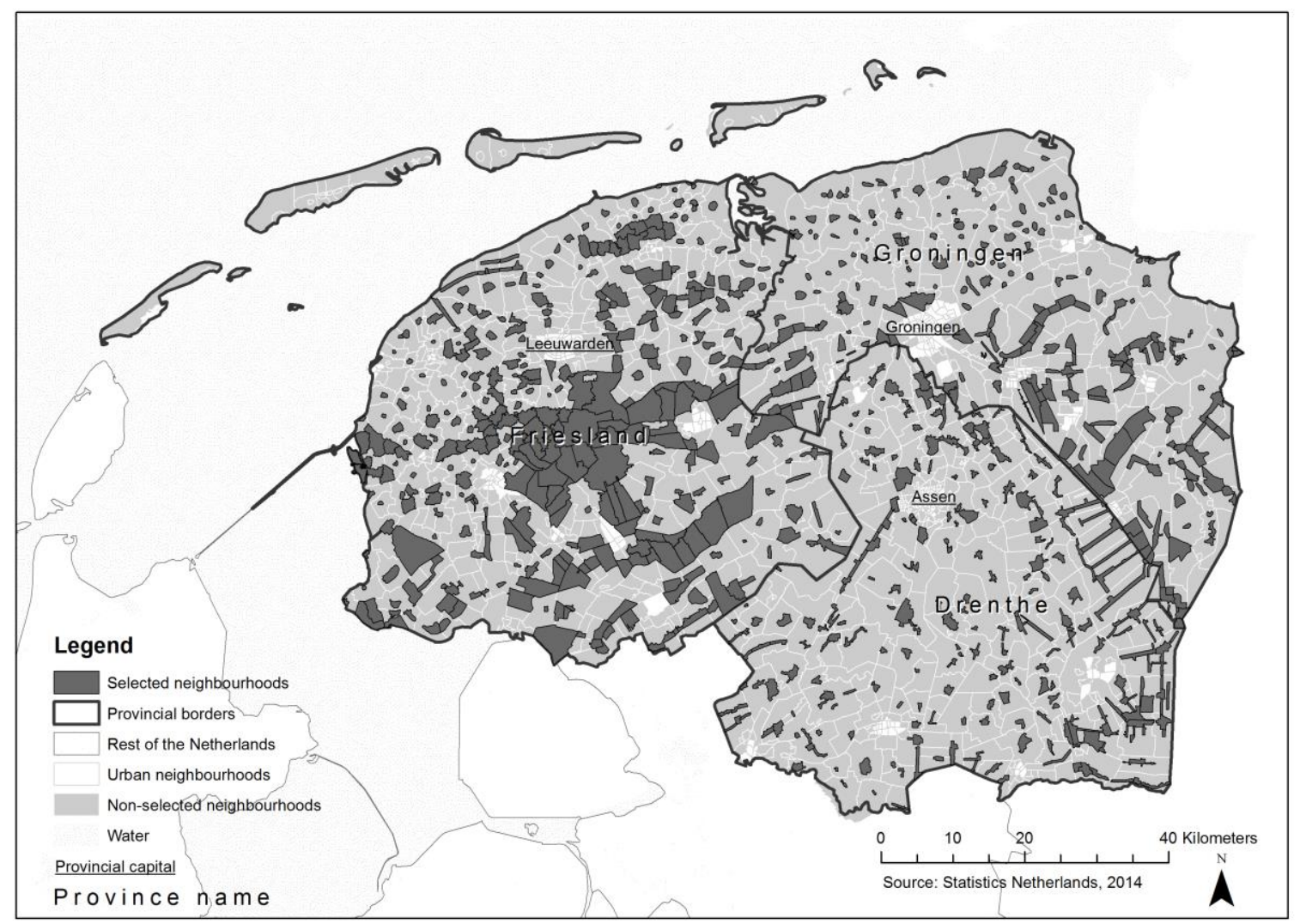

\subsection{Flows of movers}

The Dutch population register was used to determine at an individual level whether people had moved into or out of a neighbourhood during the period 1995 to 2010. This extended period was used to remove extreme annual variation of flows of movers, and to ensure that the smaller neighbourhoods had a sufficient number of moves to allow us to calculate reliable migration rates. Rates of net settlement were used to classify neighbourhoods and estimate linear regression models. The rates were calculated by dividing the total number of inward or outward moves by the total number of person years lived in the neighbourhood and multiplied by 1,000 . Indicators of net settlement were calculated in the same manner. For simplicity, these are denoted as "net settlement rates", even though they can be negative, and are therefore not true rates.

\subsection{Amenities}

Three categories of dominant soil types in North-Netherlands were identified using data from Wageningen University (2010): marine clay, former peat, and sand. For each village in the sample, the type of soil that was found to be most common in a village was identified as the dominant type of soil. Information on housing construction years was derived from the Registration of Address and Buildings from the Netherlands' Cadastre, Land Registry and Mapping Agency for 2010. The indicator we used was the percentage of buildings in four categories of construction years: before 1910 (preWWI, between 1910 and 1940, between 1945 and 1965 (years of reconstruction after WWII), and between 1995 and 2010 (newly constructed housing during the period of observation). The percentage of housing built between 1966 and 1994 was omitted to avoid over-identification of the model. Data on the locations of national monuments were obtained from the Ministry of Education, Culture, and Heritage. Using GIS, the total number of monuments was calculated per village.

Other data that measured scenic beauty involved distance measures. Data on protected natural areas from the Ministry of Economic Affairs was plotted in GIS, and road distances from the centroid of each village to the border of the nearest protected natural area were calculated. The same 
technique was used for calculating the distance to water. Only those bodies of water larger than 10 hectares were used because they provide sufficient options for recreation, such as swimming or fishing. The Waddensea on the north side and the ljsselmeer on the west side of the study area were also included.

Data on services were provided by Statistics Netherlands for the year 2011, and take two forms, both of which were used in this study: (1) the distance to a service for each household via a road network was calculated, and then the average was taken per village; and (2) for each household a service area of a certain number of kilometres was calculated, the number of services was counted, and then the average number per village was calculated. The number of restaurants within one kilometre and the number of hotels within 20 kilometres were used as a proxy of scenic beauty. The average distances to primary schools, secondary schools, general practitioners, hospitals, and supermarkets were used to operationalise service amenities. Accessibility was operationalised by using two distance variables of Statistics Netherlands: the distance to the nearest railway station and the distance to an access road of a provincially or nationally maintained main road. Furthermore, accessibility was operationalised by calculating the distance from the village centroids to the centroid of the nearest urban neighbourhood, and to the city of Utrecht. This city is in the centre of the Netherlands, and is part of the economic core of the country.

\subsection{Jobs and other village characteristics}

Two variables were used for job availability. Data on numbers of available jobs were provided by Statistics Netherlands for the year 2007, but only at the municipal level. The first variable contained all of the jobs that were available within the municipality in which the village was located. The second variable also included the jobs in municipalities that were within a 15-kilometre radius as the crow flies, measured from the centroid of the village. While boundary issues can certainly arise when using this method, such problems were minor in our analyses because the areas were small. Other explanatory variables were derived from neighbourhood statistics provided by Statistics Netherlands for the year 2011: the total number of households, address density, and the percentage of housing that was owner-occupied. Address density was defined as the number of addresses (of dwellings and firms) within one kilometre of each address, averaged per village. Address density correlates strongly with the total number of households in a village: i.e., the higher the total number of households, the higher the address density. Address density was therefore re-calculated to indicate density given the total number of households. This was done through linear regression using the total number of households as an explanatory variable of address density. The residuals for each village were then used to create a measure of relative address density. Villages with a lower address density were more likely to be stretched-out linear settlements, while villages with a higher relative address density were more likely to be compact settlements that evolved around a central point, such as a church. Finally, as an indicator of how far the village was located from the centre of the Netherlands, the Euclidian distance to Utrecht Central Station was calculated.

\subsection{Methods}

The first step in the analyses was to cluster villages according to net settlement rates per age category. This was done to provide us with some initial insight into the attractiveness of villages for certain age categories. Above-average values of net migration for a certain age category would mean that these types of villages were more attractive to people in this age category than villages in other clusters. A k-means clustering technique was used because it provides flexibility in determining the number of clusters. Furthermore, the results of this technique are easy to interpret. The number of clusters was determined by starting out with 10 clusters of villages, and dropping one cluster in each successive calculation. If the lost cluster was merely a less or a more extreme version of a remaining cluster, another cluster was dropped. In general, dropping a cluster resulted in the disappearance of small clusters that were similar to other clusters in the direction of the net settlement of the different age categories. During this process, we found that the net settlement rates of older people 
and of people of family formation ages were differentiating features in the clusters. This process finally resulted in three clusters in which these differentiating features were prominent. Finally, the means of the explanatory variables were calculated for each cluster, and one-way ANOVA was used to test the hypothesis that the means for each cluster were the same.

The second step was the estimation of a linear regression model for the inward and the outward flows of movers, and for the net settlement rates among each age category. For the inward and the outward flows, the natural logarithm was used, because the data distribution was slightly skewed to the right. For the inward flows of the age categories 60-74 and 75+, an additional TOBIT model was estimated, because in some villages there were no inward flows of people in these age categories. In addition to calculating the coefficients of independent variables for the rate of inflow, the TOBIT model calculates a probability that the rate of inflow will be above a certain threshold; in this case zero. The estimations of the TOBIT model were similar to those of the linear regression models, and are therefore not shown. 


\section{Classifying rural villages demographically}

The average net settlement rates by age category for all rural villages in North-Netherlands (see figure 2) follow the expected pattern for a rural region. On the one hand, the net settlement rate among young adults, who frequently move to cities in search of education and employment opportunities, is negative. The net settlement rate among older people is also negative. It appears that the majority of rural villages do not offer the level of services or the type of housing that older people prefer. On the other hand, the net settlement rate among people aged 30 to 60 and their dependent children (aged 0-15) is positive. These findings appear to confirm the classic notion of counterurbanisation; i.e., that rural areas are attractive to people who can afford to buy their dream home in the countryside, and who are mobile enough to be able to take advantage of the services that are located farther away.

This general picture of net settlement per age category in rural villages is made more precise by the identification of three clusters of villages. The villages gaining families cluster is characterised by stronger positive net settlement rates among the age categories $0-15$ and $30-45$. Furthermore, the net settlement rates among the age categories $15-30$ and $75+$ are more negative than average. This cluster can be seen as a more extreme version of the general picture: i.e., that families are attracted by what rural villages have to offer, whereas young adults and older people are not finding what they are looking for in rural villages. As we can see on the map (figure 3), many of the villages gaining families have fewer than 250 inhabitants, and even though they appear everywhere on the map, there are fewer such villages in the northern and eastern parts of North-Netherlands-regions that have the longest history of population decline.

The means of village characteristics by cluster type (table 1 ) indicate that, as expected, villages gaining families appear to have characteristics that are generally associated with the rural idyll. These villages seem to have relatively high levels of scenic beauty, as most have a relatively high shares of older housing, proximity to protected natural areas, and a high number of hotels within 20 kilometres. Furthermore, villages gaining families have the highest shares of housing that are owneroccupied. Villages gaining families are, on average, also the smallest of the three types, and are located relatively far away from services. As the average family owns two cars, this should not be a problem. Nevertheless, villages gaining families tend to be a relatively short distance away from a train station, and to be within 15 kilometres of municipalities with a high number of available jobs. Thus, it appears that even though these villages are in relatively remote locations, having reasonable access of jobs is important to families with children.

The second identified cluster is called villages keeping young adults. This cluster has the same strong negative net settlement rates among older people as the first cluster, but it is different because the net settlement rate among the age category $15-30$ years is much less negative. The villages in this cluster deviate from the general picture of net settlement in rural villages, because it is generally understood that young adults tend to leave rural areas. However, these villages also show a lack of positive net settlement rates among the age category 0-15 and have much lower positive net settlement rates among the age category 30-45. In contrast to villages gaining families, villages keeping young adults tend to have more than 2,500 inhabitants, and are more common in the northern and eastern parts of the study area.

Compared to villages gaining families, villages keeping young adults are less likely to be located on sandy soils, are farther away from protected natural areas, and have fewer hotels within 20 kilometres. These results seem to indicate that the villages in this cluster correspond less with the general image of the rural idyll. Moreover, villages keeping young adults have a lower percentage of owner-occupied housing, and thus a higher percentage of rental housing, which means that it is easier for young adults with fewer financial resources to live in these villages. Finally, compared to 
the other clusters, villages keeping young adults have the highest numbers of available jobs within their own municipality, but the lowest numbers of jobs in municipalities within a distance of 15 kilometres.

In contrast to the first two clusters, the third cluster is characterised by villages that are gaining people in the oldest age category, and are therefore called villages gaining older people. The net settlement rates among the other age categories in this cluster are similar to the averages for all of the villages. The main difference between the villages gaining older people and the other clusters is that these villages have above-average numbers of households. As we can see on the map, these villages are larger than average, are spread rather evenly throughout rural North-Netherlands, and are relatively far away from urban areas. Compared to the other two clusters, these villages are closer to several types of services, have more monuments, and have more restaurants located within one kilometre. It therefore appears that these villages are regional centres.

Figure 2: Clusters of villages in rural North-Netherlands

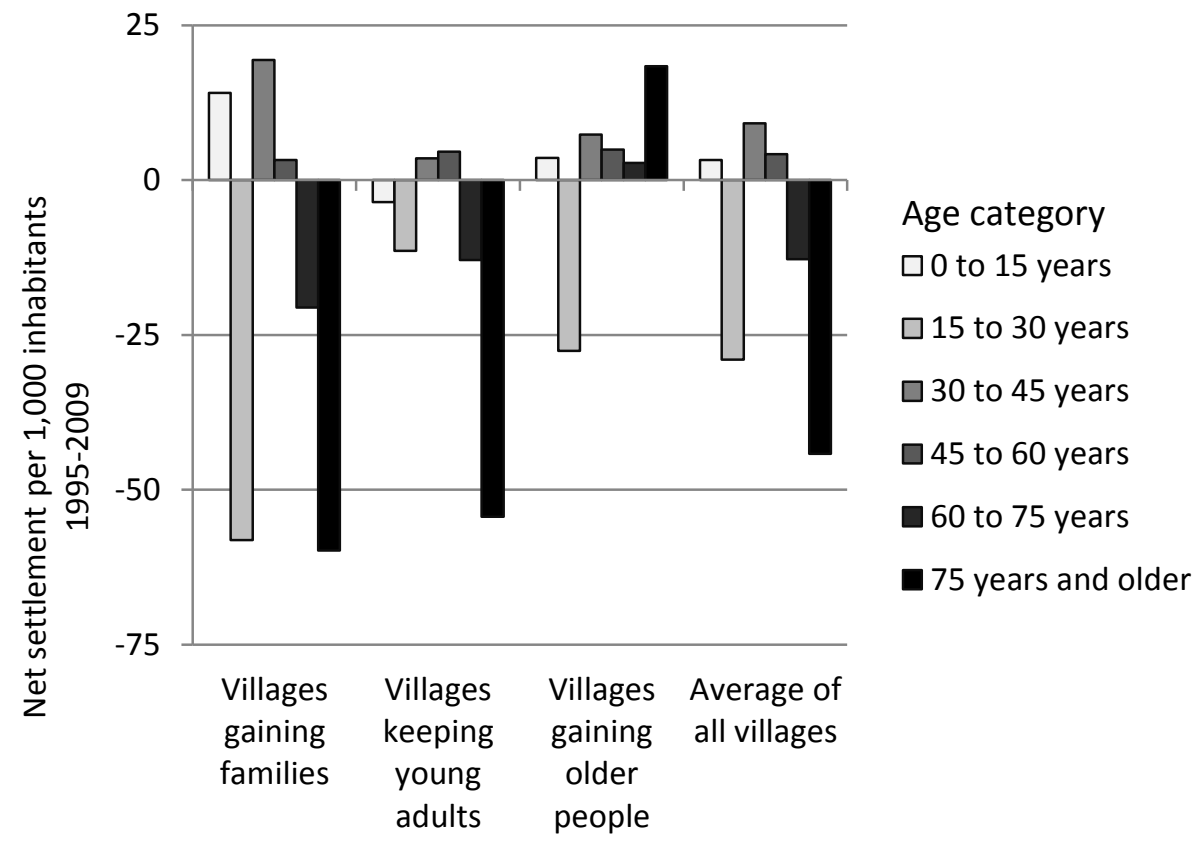


Figure 3: Map of village clusters

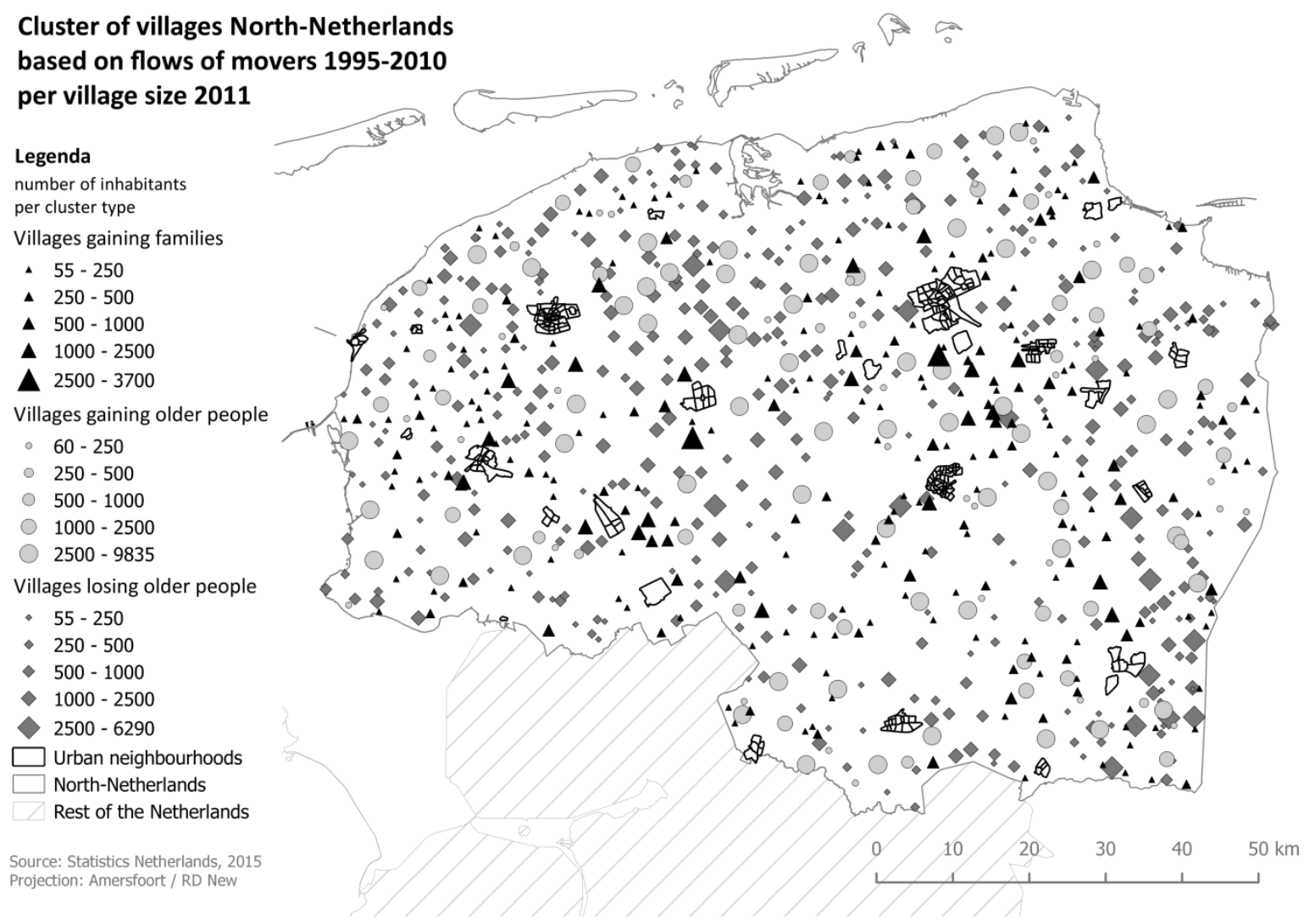


Table 1: Means of village characteristics per cluster type

\begin{tabular}{|c|c|c|c|c|}
\hline & $\begin{array}{l}\text { Villages } \\
\text { gaining older } \\
\text { people }\end{array}$ & $\begin{array}{c}\text { Villages } \\
\text { keeping } \\
\text { young adults }\end{array}$ & $\begin{array}{l}\text { Villages } \\
\text { gaining } \\
\text { families }\end{array}$ & Total \\
\hline \multicolumn{5}{|l|}{ Scenic beauty } \\
\hline \multicolumn{5}{|l|}{ Dominant soil type (\% of total villages) } \\
\hline Marine clay & 32,8 & 36,6 & 31,0 & 34,2 \\
\hline Former peat & 17,9 & 29,3 & 25,7 & $26,3 * *$ \\
\hline Sand & 49,3 & 34,2 & 43,3 & $39,6 * * *$ \\
\hline \multicolumn{5}{|l|}{ Percentage of housing } \\
\hline built before 1910 & 6,6 & 9,1 & 13,1 & $10,0 * * *$ \\
\hline built between 1910 and 1940 & 13,0 & 18,0 & 21,7 & $18,3 * * *$ \\
\hline built between 1945 and 1965 & 15,6 & 15,5 & 13,8 & $15,0 * * *$ \\
\hline Number of monuments within village & 8,8 & 3,5 & 3,2 & $4,3 * * *$ \\
\hline Distance to protected natural area $(\mathrm{km})$ & 31,1 & 33,7 & 30,9 & $32,4 *$ \\
\hline Distance to body of water ( $>10$ hectares) & 6,2 & 5,7 & 6,2 & 5,9 \\
\hline \multicolumn{5}{|l|}{ Services } \\
\hline \multicolumn{5}{|l|}{ Distance to nearest: $(\mathrm{km})$} \\
\hline Primary school & 1,0 & 1,0 & 1,5 & $1,1 * * *$ \\
\hline Secondary school & 5,0 & 6,3 & 5,8 & $5,9 * * *$ \\
\hline General practitioner & 1,7 & 2,9 & 3,1 & $2,7^{* * *}$ \\
\hline Hospital & 12,1 & 12,0 & 10,9 & $11,7^{* *}$ \\
\hline Supermarket & 1,5 & 2,7 & 3,1 & $2,6 * * *$ \\
\hline \multicolumn{5}{|l|}{ Quantity (total number within certain distance) } \\
\hline Restaurants within 1 kilometer & 1,6 & 0,6 & 0,4 & $0,7 * * *$ \\
\hline Hotels within 20 kilometers & 27,0 & 23,9 & 28,3 & $25,8 * * *$ \\
\hline \multicolumn{5}{|l|}{ Accessibility } \\
\hline \multicolumn{5}{|l|}{ Distance to: $(\mathrm{km})$} \\
\hline Economic center of the Netherlands (Utrecht) & 162,3 & 162,0 & 160,4 & 161,5 \\
\hline Nearest urban area & 10,2 & 9,4 & 9,7 & 9,7 \\
\hline Nearest large trainstation & 19,3 & 21,2 & 18,2 & $19,9 * * *$ \\
\hline Nearest main road & 1,5 & 1,8 & 2,2 & $1,9 * * *$ \\
\hline \multicolumn{5}{|l|}{ Jobs } \\
\hline \multicolumn{5}{|l|}{ Number of jobs $(x 1,000)$} \\
\hline Within own municipality & 9,5 & 12,9 & 12,6 & $12,2 *$ \\
\hline In municipalities within 15 kilometers & 126,8 & 116,8 & 133,0 & $123,6 * * *$ \\
\hline \multicolumn{5}{|l|}{ Other village characteristics } \\
\hline Total number of households in the village $(x 100)$ & 9,0 & 2,9 & 1,3 & $3,4 * * *$ \\
\hline Relative address density & 0,2 & $-0,1$ & 0,0 & $0,0 * *$ \\
\hline Owner occupied housing (\% of total housing) & 69,7 & 73,2 & 82,1 & $75,5 * * *$ \\
\hline Housing built between 1995 and 2010 (\% of total housing) & 19,3 & 17,9 & 16,3 & $17,6 * * *$ \\
\hline
\end{tabular}

One-way ANOVA $\left({ }^{* * *}=p<0.01 ;{ }^{* *}=p<0.05^{*}=p<0.1\right)$ 


\section{How village characteristics influence flows of movers of different age categories in rural villages}

\subsection{Scenic beauty}

The regression analysis in table 2 shows that the dominant soil type and the number of monuments within the village have significant effects on the net settlement rates among all ages. These findings suggest that the aspects of scenic beauty we identified as contributing to the image of the rural idyll make a village more attractive in general. The dominant soil type of a village has the most prominent significant effect on flows of movers. It appears that living in a village with marine clay or former peat rather than sandy soil has a negative effect on net migration. This can be mainly attributed to a larger outflow (see Appendix A). In other words, villages with sandy soil have a more positive net settlement rate because they have a lower outflow of people. This result corresponds with the findings of Bijker et al. (2012), which indicated that popular rural areas are more likely to be located on sandy soil than on marine clay or former peat.

The effects of scenic beauty characteristics differ by age category. In contrast to all other age categories, the net settlement rate among the age category 15-29 is higher in villages located on marine clay and former peat. It thus appears that villages with sandy soil are generally more attractive, but because housing prices in these villages tend to be higher, young adults who are starting their housing career often cannot afford to live there. This finding corresponds with those of Bijker et al. (2012), who found that less popular areas generally have a larger influx of younger movers. Furthermore, the effects of dominant soil type are shown to be insignificant among the oldest age category. This result seems to be in line with the findings of a study by Elshof et al. (2014), who found that if people aged $75+$ moved, they were more likely to do so over short distances. It therefore appears that older people are inclined to stay within the same region. Although the dominant soil type of villages within regions may vary, it is likely that the soil types of nearby villages are similar. Thus, when people aged $75+$ move, they are likely to end up in a village of the same dominant soil type, which renders the effect of dominant soil type on net settlement insignificant. 
Table 2: Linear regression models (dep. var.: Net settlement villages per 1000 inhabitants)

\begin{tabular}{|c|c|c|c|c|c|c|c|}
\hline & $\begin{array}{l}\text { All ages } \\
\text { Coef. }\end{array}$ & $\begin{array}{l}0-14 \text { years } \\
\text { Coef. }\end{array}$ & $\begin{array}{l}15-29 \text { years } \\
\text { Coef. }\end{array}$ & $\begin{array}{l}30-44 \text { years } \\
\text { Coef. }\end{array}$ & $\begin{array}{l}45-59 \text { years } \\
\text { Coef. }\end{array}$ & $\begin{array}{l}60-74 \text { years } \\
\text { Coef. }\end{array}$ & $\begin{array}{l}75+\text { years } \\
\text { Coef. }\end{array}$ \\
\hline \multicolumn{8}{|l|}{ Scenic beauty amenities } \\
\hline \multicolumn{8}{|l|}{ Dominant soil type (ref. cat: Sand) } \\
\hline Marine clay & $-3,739 * * *$ & $-10,495 * * *$ & $7,389 * *$ & $-6,931 * * *$ & $-3,598 * * *$ & $-1,694$ & $-0,809$ \\
\hline Former peat & $-1,296 *$ & $-2,884 *$ & $7,025 * * *$ & $-2,619 *$ & $-3,209 * * *$ & $-4,989 * * *$ & 1,886 \\
\hline \multicolumn{8}{|l|}{ Percentage of housing } \\
\hline built before 1910 & 0,009 & $0,149 *$ & $-0,155$ & 0,068 & 0,063 & $-0,045$ & $-0,266$ \\
\hline built between 1910 and 1940 & $-0,001$ & 0,041 & 0,091 & $0,127 * *$ & $-0,054$ & $-0,155 * *$ & $-0,335 * *$ \\
\hline built between 1945 and 1965 & 0,053 & 0,047 & 0,217 & 0,093 & $0,154 * *$ & $-0,236 * * *$ & $-0,551 * * *$ \\
\hline Number of monuments within village & $0,074 *$ & 0,049 & $-0,096$ & 0,026 & $0,147 * *$ & 0,002 & 0,258 \\
\hline Distance to protected natural area $(\mathrm{km})$ & $-0,003$ & 0,024 & 0,058 & $-0,033$ & $-0,041$ & 0,022 & $-0,074$ \\
\hline Distance to body of water ( $>10$ hectares) & $-0,012$ & 0,186 & $-0,736 * * *$ & $0,232 *$ & 0,107 & $0,269 * *$ & $-0,185$ \\
\hline \multicolumn{8}{|l|}{ Service amenities } \\
\hline \multicolumn{8}{|l|}{ Distance to nearest: $(\mathrm{km})$} \\
\hline Primary school & $-0,071$ & $-1,467 * *$ & $-2,332 * *$ & $1,253 * *$ & $1,328 * * *$ & $-2,162 * * *$ & $3,498 * * *$ \\
\hline Secondary school & $0,261 * *$ & $-0,445 *$ & $1,219 * * *$ & 0,184 & $0,598 * * *$ & $0,552 * * *$ & $-0,427$ \\
\hline General practitioner & 0,173 & $-0,724$ & $2,539 * * *$ & $-0,400$ & $0,554 *$ & $-0,383$ & 0,251 \\
\hline Hospital & $-0,061$ & $-0,483 * * *$ & $-0,016$ & $-0,172$ & $0,170 * *$ & 0,139 & 0,188 \\
\hline Supermarket & $-0,074$ & $-0,271$ & $-0,169$ & 0,619 & 0,078 & $-0,939 * *$ & $-1,150$ \\
\hline \multicolumn{8}{|l|}{ Quantity (total number within certain distance) } \\
\hline Restaurants within 1 kilometer & $0,708 * *$ & 0,079 & $-0,398$ & 0,448 & $1,525 * * *$ & $2,355 * * *$ & 0,659 \\
\hline Hotels within 20 kilometers & $-0,019$ & 0,073 & $-0,485 * * *$ & $0,112 *$ & 0,072 & $-0,036$ & $-0,334 * *$ \\
\hline \multicolumn{8}{|l|}{ Accessibility } \\
\hline \multicolumn{8}{|l|}{ Distance to :(km) } \\
\hline Economic center of the Netherlands (Utrecht) & $-0,015$ & 0,004 & $-0,095 * *$ & $-0,011$ & $-0,003$ & $-0,018$ & 0,033 \\
\hline Nearest urban area $(\mathrm{km})$ & 0,060 & $-0,007$ & 0,207 & $-0,069$ & $-0,027$ & 0,042 & 0,013 \\
\hline Nearest trainstation $(\mathrm{km})$ & 0,067 & $-0,037$ & $-0,037$ & $-0,109$ & $0,174 * *$ & $0,199 *$ & 0,247 \\
\hline Nearest main road $(\mathrm{km})$ & $-0,085$ & 0,621 & $-2,335 * * *$ & $0,707 *$ & $-0,052$ & 0,220 & 0,666 \\
\hline \multicolumn{8}{|l|}{ Jobs } \\
\hline \multicolumn{8}{|l|}{ Number of jobs $(x 1,000)$} \\
\hline Within own municipality & 0,005 & 0,041 & 0,034 & 0,007 & 0,014 & $-0,014$ & 0,049 \\
\hline In municipalities within 15 kilometers & $-0,010 *$ & 0,004 & $-0,006$ & $0,017 *$ & $-0,038 * * *$ & $-0,015$ & 0,019 \\
\hline \multicolumn{8}{|l|}{ Other village characteristics } \\
\hline Total number of households in the village $(x 100)$ & $0,296 * * *$ & 0,131 & 0,467 & 0,074 & $-0,197$ & $0,750 * * *$ & $2,619 * * *$ \\
\hline Relative address density & $0,751 * *$ & $1,801 * *$ & $-0,406$ & $1,401 * *$ & 0,168 & $1,176 *$ & $2,948 * *$ \\
\hline Population own age category in 1995 (\% of total population) & $x$ & $-0,933 * * *$ & 0,278 & $-0,887 * * *$ & $-0,001$ & $-0,167$ & $1,902 * * *$ \\
\hline Owner occupied housing (\% total housing) & 0,008 & $0,446 * * *$ & $-0,600 * * *$ & $0,406 * * *$ & $-0,001$ & $-0,327 * * *$ & 0,035 \\
\hline Housing built between 1995 and 2010 (\% of total housing) & $0,355 * * *$ & $0,174 * *$ & $0,724 * * *$ & $\quad 0,346 * * *$ & $0,392 * * *$ & $0,299 * * *$ & 0,066 \\
\hline Constant & $-10,163 * * *$ & $-7,886$ & 11,413 & $-13,039 *$ & $-9,772 *$ & $15,324^{* *}$ & $-52,218^{* * *}$ \\
\hline R-square & 0,248 & 0,240 & 0,217 & 0,245 & 0,200 & 0,393 & 0,255 \\
\hline $\mathrm{N}$ & 865 & 865 & 866 & 872 & 869 & 863 & 851 \\
\hline
\end{tabular}

The importance of scenic beauty amenities is further exemplified by the positive effects of the number of monuments on the total net settlement rate. This positive effect on the total net settlement rate can be largely ascribed to the positive effect on the net settlement rate among people aged 45-59. Other village characteristics that are classified as scenic beauty amenities do not have significant effects on the total net settlement rate, but do influence the net settlement rates among specific age categories. Being farther away from a large body of water has a positive effect on the net settlement rates among people aged 30-44 and 60-74, while it has a negative effect on the net settlement rates among people aged 15-29. The villages with a large share of housing built between 1910 and 1965 have low net settlement rates among people aged 60 and older. However, the villages with a large share of housing built between 1910 and 1940 have high net settlement rates among people aged 30-44. It is likely that people in this age category find the larger 'rentenierswoning' attractive for starting or expanding their family, and are thus likely to move to a village with this type of housing. Furthermore, villages with a large share of post-war housing (built 1945 to 1965) have high net settlement rates among people aged 45-59 and low net settlement rates among people aged 60 and older.

\subsection{Other amenities}

We find no significant effect of a nearby primary school on the total net settlement rates in villages. This observation corresponds with the results of the existing literature, which found that the effect of a nearby primary school on moving behaviour is limited. This limited effect is, however, the result of significant positive and negative effects on the net settlement rates among different age categories. The villages that are farther away from primary schools have lower net settlement rates among the 
two youngest age categories, but higher net settlement rates among people aged 30-64. This result is rather surprising, because it may be expected that the direction of the effect of a primary school would be similar for the children (aged 0-14) and the likely parents (aged 30-44).

The net settlement rate is more positive in villages that are farther away from a secondary school. This pattern may be attributable to the belief that secondary school pupils are a nuisance. This assumption is supported by the finding that the effect among the older age categories can be mostly explained by significantly higher inward flows to villages located farther away from a secondary school. Moreover, the effect of distance to a secondary school is negative for the net settlement rate among the age category 0-14. Their parents might be inclined to live closer to the school that their children attend or will attend in the future. Thus, for families with children, a secondary school might be an amenity.

The distance to the remaining three types of services (general practitioners, hospitals, and supermarkets) do not have significant effects on the total net settlement rate. However, among the age category 45-59 the effects of all of these service amenities on net settlement is positive, which implies that the net settlement rate is higher in villages that are farther away from services. An expected negative effect of increasing distance to a supermarket was found among the age category 60-74, which can be attributed to higher than average outward flows. Surprisingly, no effects on net settlement rates are found for distance to health services among the older age categories, as we would expect to observe a negative effect when distance to these services increases. This finding could be related to the greater probability that these services are available in larger villages. Indeed, when the total number of households is removed from the model, the distance to a general practitioner has a negative effect on the net settlement rate among the age category 60-74. Moreover, a significant negative effect of distance to a supermarket appears among the age category $75+$. While older people clearly prefer to live close to health services and supermarkets, in the model this preference translates into a positive effect of the total number of households in the village on the net settlement rates among the older age categories.

No effect was found for village characteristics related to accesibility on the total net settlement rate in rural villages. This is a rather unexpected result, because research by Bijker et al. (2012) showed that the distance to the economic core area of the Netherlands has an effect on the popularity of municipalities as measured by housing value. Furthermore, Gzartkios and Scott (2009) found in Ireland that rural places close to railways and main roads have higher growth rates than more perpiheral areas. Significant effects for accessibility characteristics are, however, found for the net settlement rates among certain age categories. The villages that are closer to Utrecht and to main roads are more likely to have a positive net settlement rate among people aged 15-29. People in this age category prefer to live in villages that are less remote. However, a significant positive effect on the net settlement rate is found for distance to a main road among people in the age category 30-44. Among the age categories 45-59 and 60-74, net migration is more positive in villages that are farther away from a railway station.

\subsection{Jobs and other village characteristics}

The results for the effect of the availability of jobs on net migration are counterintuitive. We would expect to find that the net settlement rate would be higher in places that have more jobs within their own municipality or in municipalities nearby. Instead, table 2 shows that the higher the number of jobs in municipalities within 15 kilometers, the lower the net settlement. This finding can be mainly attributed to the negative effect of having a higher number of jobs in municipalities within 15 kilometers among the age category 45-59. A possible reason for this finding could be that the net settlement rate among the age category 45-59 is highest in some parts of Drenthe en Friesland with forests or lakes that are not close to urban centers. However, the villages with more jobs in municipalities within 15 kilometers have more positive net migration rates among the age category 
30-44. Living in a village that is relatively close to a municipality with a large number of jobs thus appears to be most attractive to people in the earlier stages of their working career.

Other explanatory variables in the model were related to demographic characteristics. First, we observed that the larger the size of the village, the more positive the net settlement, but only among the two oldest age categories. This finding may be related to the higher number of services in larger villages, but also to the higher number of homes for the elderly in such villages. The observation that larger villages are especially attractive to older people is further reinforced by the finding that a higher number of households has a positive effect on the influx of people aged 75 and older, and by the unexpected finding that a higher number of households does not have a negative effect on the influx of people aged 60-74.

Second, there is a positive effect on net settlement for villages with a higher address density. This may be caused by the different ways in which some the villages developed over the centuries. On the one hand, there are villages that have developed outwards from a single centre, such as villages based on dwelling mounds. Villages of this type tend to be more compact and to contain more historical elements. On the other hand, there are villages that have developed next to a canal or road. These villages can stretch over several kilometres with only a single line of housing on each side of the canal or road. Villages that were founded during the peat excavations in the $19^{\text {th }}$ century are good examples of this type. They are often situated in open landscapes, and contain relatively few historical elements. In general, the residential environment of the first category of villages is valued over the second category.

Third, only the presence of a higher share of people in the age category $75+$ results in a more positive net settlement rate among the same age category. The availability of homes for the elderly probably explains why people in the oldest age category are attracted to these villages. A significant negative effect on the net settlement rates among the age categories 0-14 and 30-44 was found for higher shares of people in the same age category. This dynamic is caused by a relatively strong negative effect on inward flows, which suggests that each village has only a certain amount of housing that is considered suitable for families with children (who are mainly in this age category). Once these houses are filled - a process that is reflected in the relatively high percentage of people in this age category at the start of the measurement - there might be no suitable housing left for new families with children.

Although population decline may have caused the demand for housing in rural areas in NorthNetherlands to decrease to some extent, the net settlement rate is more positive in villages where the construction of new housing that appeals to contemporary residential preferences took place during the period of observation. Indeed, new construction is one of the strongest explanatory variables in the models. This observation is valid among almost every age category, except among people aged 75 and older. The net settlement rate among the age categories 0-14 and 30-44 is higher in villages with larger shares of owner-occupied housing. As previous research has shown (e.g., Mulder 2006), family formation is often accompanied by becoming a home owner. People aged 30 to 44 are likely to form a family and thus to buy a home, which they are more likely to find in a village that has a higher share of owner-occupied housing. Conversely, it is likely that many people in the other age categories either cannot afford to buy a home (aged 15-29), or are too old to make the commitment of buying a home, and thus prefer to move to rented housing (aged 60-74). 


\section{Conclusion}

In this paper, we showed that patterns of moving flows within rural regions are heterogeneous. Some villages in rural North-Netherlands are attractive because they have characteristics that reflect the notion of the rural idyll: i.e., they are small, relatively remote, nuclear villages in half-open landscapes that offer many opportunities to buy a house. Moreover, because they have positive net settlement rates among people aged 30-60, they can be seen as epitomes of counterurbanisation. The characteristics of the other villages are less in line with the image of the rural idyll. Nevertheless, these villages can still be attractive to people in specific age categories. The net settlement rate among young adults is much less negative in less remote villages in open landscapes with more options to rent a house. The net settlement rate among older people is positive in larger villages that can be seen as regional centres. These findings add to the literature by showing that at the low-scale level of villages, rural migration is more than a process of counterurbanisation, and that villages that do not have characteristics typically associated with the rural idyll can still be attractive to people of specific ages.

In line with Stockdale's (2015) argument regarding 'messy' rural migration, our estimates of the effects of village attractiveness on flows of movers in different age categories revealed a somewhat 'messy' picture. In terms of total net settlement in villages, some of the effects of village characteristics were as expected: for example, sand as the dominant soil type was found to have a positive influence. Other expected effects of village characteristics were not confirmed, such as the expected positive influence of being close to protected natural areas; or were even found to go in the opposite direction, such as the expected positive effect of having more jobs within a reasonable distance of the village. In general, it was revealed that scenic beauty amenities affect total net settlement of rural villages to some extent; but that other village characteristics, such as village size, village density, and newly built housing, were very dominant.

Our findings show that village characteristics that are attractive to people of a certain age seem to be unattractive to people of another age. Opposite effects were most often found among young adults and families with children, which corresponds to the relationship that was found between the net settlement patterns of young adults and families with children in the cluster analysis. For example, if the dominant soil type in a village was marine clay or former peat, there was a positive effect on net settlement among young adults, but a negative effect on net settlement among families with children. Being far from a main road and having a higher share of owner-occupied housing had a negative effect on net settlement among young adults, but a positive effect on net settlement among families with children.

Although moving distance and the personal characteristics of the movers were not included in this study, the moving flows of young adults and families with children might indicate the types of people who are moving to particular types of villages. As we observed that the villages that gain families but lose many young adults are often located in more remote areas with higher levels of scenic beauty, it may well be the case that these villages attract those who seek aspects of the rural idyll, which is in line with the classical notion of counterurbanisation. People who undertake these kinds of moves tend to move over longer distances, and are likely to be highly educated (Halfacree 2008). Their children are also likely to be highly educated, and to be less rooted in their village because their parents are not originally from the area. Therefore, when these children reach young adulthood, it may be assumed that they are also more likely to move to an urban area located far away. Hence, a positive settlement rate among families with children and a strong negative net settlement rate among young adults was found. Villages that keep young adults tend to be located in areas dominated by marine clay and former peat, which are considered to be less popular. These villages therefore tend to receive movers from other rural areas who are less educated (Bijker et al. 2012). It is also assumed that these movers are generally younger, which corresponds with the findings in this study. Given the evidence showing that moving behaviour differs by educational level, future 
research should investigate whether particular villages are mainly inhabited by less educated people, whereas other villages are mainly inhabited by highly educated people.

Some village characteristics had a unidirectional effect on the net settlement rate among specific age categories. The most prominent characteristic was the total number of households, which had a strong positive effect on the net settlement rate among older people. Our finding that only larger villages had a positive net settlement rate among older people complicates the general assumption that certain regions are experiencing both population decline and population ageing. In our study area, we found that at the local level, ageing is mitigated in smaller villages because older people move out, but is intensified in larger villages because older people move in.

A surprising result of this study was that village characteristics related to nearby services and jobs had little effect on net settlement in rural villages. Apparently, for many people in the rural areas of North-Netherlands, distance is not an issue. In the context of population decline this is a comforting result, because it suggests that the closure of services is not likely to greatly influence net settlement in villages. Our finding that distances hardly matter can be partly attributed to the size of the region. Although the Dutch consider the area to be rural, it far less remote than, for example, some rural areas of Sweden or Canada. All of the villages in our study are less than 30 kilometres from the nearest urban area, and are little more than 200 kilometres from the centre of the Netherlands. This means that the residents of these villages are reasonably close to municipalities with jobs and urban amenities. The results of this study are therefore not easily translated to other rural areas, but may be comparable to the experiences of other peri-urban regions.

The potential impact of the presence of a primary school in a village is much debated in the context of population decline, but previous research has shown that this factor has little to no effect on flows of movers. In this study, we found that distance to a primary school has no effect on the total net settlement rate. This finding was, however, the result of several contrasting effects for different age categories. We found negative net settlement rates among the age categories under 30 with increasing distance to a primary school, but positive net settlement rates among the age categories 30-59. These findings contradict those of earlier studies, which showed that the effect of the presence of a primary school on moving is rather insignificant. Moreover, these results appear to contradict the hypothesis that a nearby primary school attracts all people of typical childbearing ages. Further investigation of the relationship between the presence of primary schools and moving behaviour is therefore needed.

Contrasting effects of village characteristics on net settlement rates by age category were also found for other services. This finding might appear to suggest that policymakers could direct flows of movers in some desired way by dispersing services in a specific manner. Furthermore, it may be falsely assumed that building new housing would be an effective way of increasing net settlement in villages. However, policymakers should be cautious in employing these strategies in a context of population decline, because the declining population could cause people to make trade-offs between villages. This means that when people move into new housing in one village, they will not move into the new housing in the next village. Plans for new housing construction should therefore be made on a regional scale. Moreover, the declining population can also cause a trade-off to occur within villages, with people moving into new housing from existing housing that remains empty afterwards. Thus, plans for new housing construction in declining regions should also take the demolition of existing housing into consideration. 


\section{References}

Amcoff, J. (2012). Do rural districts die when their schools close? Evidence from Sweden around 2000. Educational Planning, 20, 47-60.

Argent, N., Smailes, P. and Griffin, T. (2007). The amenity complex: towards a framework for analysing and predicting the emergence of a multifunctional countryside in Australia. Geographical Research, 45, 217-232. doi: 10.1111/j.1745-5871.2007.00456.x

Argent, N., Tonts, M., Jones, R. and Holmes, J. (2009). Rural amenity and rural change in temperate Australia: Implications for development and sustainability. Journal for Geography, 4(2), 15-28.

Argent, N., Tonts, M., Jones, R. and Holmes, J. (2014). The amenity principle, internal migration, and rural development in Australia. Annals of the Association of American Geographers, 104(2), 305-318.

Barakat, B. (2015). A 'recipe for depopulation'? School closures and local population decline in Saxony. Population, Space and Place, 21(8), 735-753. doi: 10.1002/psp.1853.

Barr, N. (2002). Victoria's small farms. CLPR Research report No. 10. Epsom: Department of Natural Resources and Environment.

Bollman R. D. and Briggs, B. (1992). Rural and small town Canada: an overview. In Bollman R. D. (ed.) Rural and small town Canada, (pp 337-357). Toronto: Thompson Educational Publishing.

Bontje, M., and Musterd, S. (2012). Understanding shrinkage in European regions. Built Environment, 38(2), 153-161.

Boyle, P., Halfacree, K. H., and Robinson, V. (1998). Exploring contemporary migration. Routledge.

Bijker, R. A., Haartsen T. and Strijker, D. (2012). Migration to less-popular rural areas in the Netherlands: Exploring the motivations. Journal of Rural Studies, 28(4), 490-498. doi:

10.1016/j.jrurstud.2012.07.003.

Bijker, R. A., Haartsen, T. and Strijker, D. (2013). Different areas, different people? Migration to popular and less-popular rural areas in the Netherlands. Population, Space and Place, 19(5), 580-593. doi: 10.1002/psp.1741

Brandes, S. H. (2013). Migration, kinship, and community: tradition and transition in a Spanish village. New York: Academic Press.

Brueckner, J. K., Thisse, J. F., and Zenou, Y. (1999). Why is central Paris rich and downtown Detroit poor? An amenity-based theory. European Economic Review, 43(1), 91-107.

Can, A. (1992). Specification and estimation of hedonic housing price models. Regional Science and Urban Economics, 22(3), 453-474.

Champion, A. (1999). Urbanization and counter-urbanization. Applied Geography. Principle and Practice, 347-357.

Clark, W. A. V. and Dieleman, F. M. (1996). Households and housing: Choice and outcomes in the housing market. New Jersey: Center for Urban Policy Research. 
Courgeau, D. (1985) Interaction between spatial mobility, family, and career life-cycle: a French survey, European Sociological Review, 1, 139-162.

Deller, S., Tsai, S., Marcouller, D. and English, D. (2001). The role of amenities and quality of life in rural economic growth. American Journal of Agricultural Economics, 83, 352-365.

Dieleman, F. M. (2001). Modelling residential mobility; a review of recent trends in research. Journal of Housing and the Built Environment, 16, 249-265.

Dustmann, C., and Okatenko, A. (2014). Out-migration, wealth constraints, and the quality of local amenities. Journal of Development Economics, 110, 52-63.

Elshof, H., Van Wissen, L.J.G. and Mulder, C.H. (2014). The self-reinforcing effects of population decline: An analysis of differences in moving behavior between rural neighbourhoods with declining and stable populations. Journal of Rural Studies, 36, 285-299.

Elshof, H. and Bailey, A. (2015a). The role of responses to experiences of rural population decline in the social capital of families. The Journal of Rural and Community Development, 10(1), 72-93.

Elshof, H., Haartsen, T. and Mulder C.H. (2015b). The effect of primary school absence and closure on inward and outward flows of families. Tijdschrift voor Economische en Sociale Geografie, 106(5), 625-635. doi: 10.1111/tesg.12172

Fielding, A. J. (1992). Migration and social mobility: South East England as an escalator region. Regional Studies, 26(1), 1-15.

Gardner, P. J. (2011). Natural neighborhood networks - Important social networks in the lives of older adults aging in place. Journal of Aging Studies, 25(3), 263-271.

Gkartzios, M. and Scott, M. (2009). Residential mobilities and house building in rural Ireland: evidence from three case studies, Sociologia Ruralis, 50, 64-84.

Grimsrud, G. M. (2011). How well does the 'counter-urbanisation story' travel to other countries? The case of Norway. Population, Space and Place, 17(5), 642-655.

Haartsen, T., Huigen, P. P. P. and Groote, P. (2003). Rural areas in the Netherlands. Tijdschrift voor Economische en Sociale Geografie, 94(1), 129-136.

Haartsen T. and Strijker D. (2010). Rural youth culture: keten in the Netherlands. Journal of Rural Studies, 26, 163-172.

Haartsen, T. and Venhorst, V.A. (2010). Planning for decline: anticipating on population decline in the Netherlands. Tijdschrift voor Economische en Sociale Geografie, 101(2), 218-227.

Haartsen, T., and Thissen, F. (2014). The success-failure dichotomy revisited: young adults' motives to return to their rural home region. Children's Geographies, 12(1), 87-101.

Halfacree, K. H. (1995). Talking about rurality: social representations of the rural as expressed by residents of six English parishes. Journal of Rural Studies, 11(1), 1-20.

Halfacree, K. (2008). To revitalize counterurbanization research? Recognising an international and fuller picture. Population, Space and Place, 14, 479-495. 
Helderman, A. C., Mulder, C. H., and Van Ham, M. (2004). The changing effect of home ownership on residential mobility in the Netherlands, 1980-98. Housing Studies, 19(4), 601-616.

Johnson K.M. and Beale C.L. (1994). The recent revival of widespread population growth in nonmetropolitan areas of the United States. Rural Sociology, 59, 655-667.

Kim, J. H., Pagliara, F., and Preston, J. (2005). The intention to move and residential location choice behaviour. Urban Studies, 42(9), 1621-1636.

McGranahan, D.A. (1999). Natural amenities drive rural population change. Washington, DC : Department of Agriculture, Economic Research Service.

McGranahan, D.A. (2008). Landscape influence on recent rural migration in the U.S. Landscape and Urban planning, 85, 228-240.

Milbourne P. (2007). Re-populating rural studies: migrations, movements and mobilities. Journal of Rural Studies, 23, 381-386.

Mulder, C. H. (2006). Home-ownership and family formation. Journal of Housing and the Built Environment, 21(3), 281-298.

Niedomysl, T., and Clark, W. A. (2014). What matters for internal migration, jobs or amenities?. Migration Letters, 11(3), 377-386.

Nilsson, P. (2016). Are valuations of place-based amenities driven by scale?. Housing Studies, 1-21.

Partridge, M. D. (2010). The duelling models: NEG vs amenity migration in explaining US engines of growth. Papers in Regional Science, 89(3), 513-536.

Polinsky, A. M., and Rubinfeld, D. L. (2013). Property values and the benefits of environmental improvements: Theory and measurement. Public Economics and the Quality of Life, 154.

Rees, P., van Imhoff, E., Durham, H., Kupiszewski, M., and Smith, D. (1998). Internal migration and regional population dynamics in Europe: Netherlands case study.

Rossi, P. (1955). Why families move: a study in the social psychology of residential mobility. Glencoe, II: Free Press.

Smailes, P., Griffin, T., Argent, N. (2005). The changing social framework. In: Cocklin, C., Dibden, J. (Eds.) Sustainability and change in rural Australia. Sydney: UNSW Press.

Statistics Netherlands (2015). Definition: Neighbourhood area. Retrieved from http://www.cbs.nl/en-

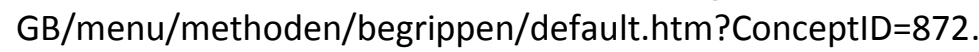

Statistics Netherlands (2016) Statline. Retrieved from http://statline.cbs.nl/statweb.

Stockdale, A. (2006). Migration: Pre-requisite for rural economic regeneration?. Journal of Rural Studies, 22(3), 354-366.

Stockdale, A., and Catney, G. (2014). A life course perspective on urban-rural migration: The importance of the local context. Population, Space and Place, 20(1), 83-98. doi: 10.1002/psp.1758 
Stockdale, A. (2015). Contemporary and 'messy' rural in-migration processes: Comparing counterurban and lateral rural migration. Population, Space and Place.

Tacken, M. (1998). Mobility of the elderly in time and space in the Netherlands: An analysis of the Dutch National Travel Survey. Transportation, 25(4), 379-393.

Thissen, F., Fortuijn, J. D., Strijker, D., and Haartsen, T. (2010). Migration intentions of rural youth in the Westhoek, Flanders, Belgium and the Veenkoloniën, The Netherlands. Journal of Rural Studies, 26(4), 428-436.

Thissen, F. and Loopmans, M. (2013). Dorpen in verandering. Rooilijn, 46(2), 80-89.

Ulrich, R. S. (1986) 'Human responses to vegetation and landscapes', Landscape and Urban Planning, $13,29-44$.

Van Dam, F., Heins, S. and Elbersen B.S. (2002). Lay discourses of the rural and stated and revealed preferences for rural living: some evidence of the existence of a rural idyll in the Netherlands. Journal of Rural Studies, 18, 461-476.

Van Ham, M. (2002). Job access, workplace mobility, and occupational achievement. Delft: Eburon.

Van der Molen, F. (1993). Woongedrag en huisvesting van ouderen. Groningen: Wolters-Noordhoff.

Verwest, F., Sorel, N. and Buitelaar, E. (2008). Regionale krimp en woningbouw: omgaan met een transformatieopgave. Rotterdam: Nai Uitgevers.

Wageningen University (2010). Grondsoortenkaart.

http://www.geodata.alterra.nl/Grondsoorten.htm

Walford, N. (2007). Geographical and geodemographic connections between different types of small area as the origins and destinations of migrants to Mid-Wales. Journal of Rural Studies, 23(3), 318331. doi:10.1016/j.jrurstud.2007.01.007.

Westlund H. (2002). An unplanned green wave: settlement patterns in Sweden during the 1990s. Environment and Planning A, 34, 1395-1410. 


\section{Appendix A - Linear regression model of inward and outward flows}

\begin{tabular}{|c|c|c|c|c|c|c|c|c|c|}
\hline $\begin{array}{l}\text { Linear regression models (dep. var. Inward flows per 1,000 } \\
\text { population) }\end{array}$ & $\begin{array}{l}\text { All ages } \\
\text { Coef. }\end{array}$ & & $\begin{array}{l}0-14 \text { years } \\
\text { Coef. }\end{array}$ & & $\begin{array}{l}15-29 \text { years } \\
\text { Coef. }\end{array}$ & $\begin{array}{l}30-44 \text { years } \\
\text { Coef. }\end{array}$ & $\begin{array}{l}45-59 \text { years } \\
\text { Coef. }\end{array}$ & $\begin{array}{l}60-74 \text { years } \\
\text { Coef. }\end{array}$ & $\begin{array}{l}75+\text { years } \\
\text { Coef. }\end{array}$ \\
\hline \multicolumn{10}{|l|}{ Scenic beauty amenities } \\
\hline \multicolumn{10}{|l|}{ Dominant soil type (ref. cat: Sand) } \\
\hline Marine clay & 0,014 & & $-0,015$ & & $0,054 * *$ & $-0,024$ & $-0,077 *$ & $-0,039$ & $-0,096$ \\
\hline Former peat & 0,000 & & 0,001 & & 0,024 & 0,000 & $-0,081 * *$ & $-0,028$ & 0,056 \\
\hline \multicolumn{10}{|l|}{ Percentage of housing } \\
\hline built before 1910 & $-0,001$ & & $-0,004$ & ** & 0,000 & 0,000 & 0,000 & $-0,002$ & $-0,016 * * *$ \\
\hline built between 1910 and 1940 & 0,003 & *** & 0,005 & *** & $0,003 * * *$ & $0,006 * * *$ & 0,001 & $-0,007 * *$ & $-0,003$ \\
\hline built between 1945 and 1965 & 0,001 & & 0,000 & & 0,002 & 0,001 & $0,004 *$ & $-0,010 * *$ & $-0,015 * *$ \\
\hline Number of monuments within village & 0,000 & & $-0,001$ & & 0,002 & 0,000 & 0,003 & 0,000 & 0,006 \\
\hline Distance to protected natural area $(\mathrm{km})$ & 0,000 & & 0,000 & & $-0,001$ & $-0,001$ & $-0,001$ & 0,003 & $-0,001$ \\
\hline Distance to body of water ( $>10$ hectares) & 0,004 & $*$ & 0,006 & * & 0,000 & $0,008 * * *$ & 0,001 & 0,004 & $-0,003$ \\
\hline \multicolumn{10}{|l|}{ Service amenities } \\
\hline \multicolumn{10}{|l|}{ Distance to nearest: $(\mathrm{km})$} \\
\hline Primary school & 0,029 & *** & 0,007 & & $0,024 * *$ & $0,051 * * *$ & $0,035 * *$ & $-0,047 *$ & $-0,109 * *$ \\
\hline Secondary school & 0,000 & & $-0,003$ & & $-0,004$ & $-0,001$ & $0,011 * *$ & $0,023 * *$ & $-0,018$ \\
\hline General practitioner & 0,008 & & 0,005 & & 0,011 & 0,006 & $0,021 * *$ & $-0,004$ & 0,001 \\
\hline Hospital & $-0,002$ & & $-0,007 *$ & *** & $-0,004 *$ & $-0,002$ & $0,006 * *$ & $0,014^{* *}$ & 0,000 \\
\hline Supermarket & 0,011 & & 0,008 & & 0,007 & $0,017 * *$ & 0,006 & 0,016 & $-0,035$ \\
\hline \multicolumn{10}{|l|}{ Quantity (total number within certain distance) } \\
\hline Restaurants within 1 kilometer & 0,012 & & $-0,004$ & & 0,004 & 0,008 & $0,048 * * *$ & $0,067 * *$ & $-0,001$ \\
\hline Hotels within 20 kilometers & 0,002 & * & 0,001 & & 0,000 & $0,004 * * *$ & $0,003 *$ & 0,002 & $-0,003$ \\
\hline \multicolumn{10}{|l|}{ Accessibility } \\
\hline \multicolumn{10}{|l|}{ Distance to :(km) } \\
\hline Economic center of the Netherlands (Utrecht) & 0,000 & & 0,000 & & $-0,001$ & 0,000 & 0,000 & $-0,001$ & 0,002 \\
\hline Nearest urban area $(\mathrm{km})$ & 0,001 & & $-0,001$ & & $0,003 *$ & $-0,002$ & $-0,002$ & 0,001 & $-0,010$ \\
\hline Nearest trainstation $(\mathrm{km})$ & 0,002 & & 0,003 & & $-0,002$ & 0,000 & $0,011 * * *$ & $0,018 * * *$ & $0,014 *$ \\
\hline Nearest main road $(\mathrm{km})$ & $-0,012$ & $* *$ & $-0,010$ & & $-0,013 * *$ & $-0,007$ & $-0,015$ & 0,003 & $-0,004$ \\
\hline \multicolumn{10}{|l|}{ Jobs } \\
\hline \multicolumn{10}{|l|}{ Number of jobs $(x 1,000)$} \\
\hline Within own municipality & 0,000 & & 0,000 & & 0,000 & 0,000 & 0,001 & 0,000 & 0,001 \\
\hline In municipalities within 15 kilometers & 0,000 & $* *$ & 0,000 & & 0,000 & 0,000 & $-0,001 * * *$ & $-0,002 * * *$ & $-0,001$ \\
\hline \multicolumn{10}{|l|}{ Other village characteristics } \\
\hline Total number of households in the village $(x 100)$ & $-0,007$ & *** & $-0,005$ & & $-0,008 * * *$ & $-0,006 * *$ & $-0,016 * * *$ & 0,008 & $0,051 * * *$ \\
\hline Relative address density & 0,046 & *** & $0,071 *$ & *** & $0,032 * * *$ & $0,058 * * *$ & 0,025 & 0,041 & $0,113 * *$ \\
\hline Population own age category in 1995 (\% of total population) & $\mathrm{x}$ & & $-0,033$ & *** & $-0,010^{* * *}$ & $-0,022 * * *$ & $0,006 *$ & $0,014 * *$ & $0,054 * * *$ \\
\hline Owner occupied housing (\% total housing) & $-0,006$ & *** & $-0,005$ & *** & $-0,007 * * *$ & $-0,003 * * *$ & $-0,005 * * *$ & $-0,014 * * *$ & $-0,005$ \\
\hline Housing built between 1995 and 2010 (\% of total housing) & 0,007 & *** & $0,006 *$ & *** & $0,008 * * *$ & $0,007 * * *$ & $0,011 * * *$ & $0,015 * * *$ & $0,018 * * *$ \\
\hline Constant & 4,353 & *** & $4,901 *$ & *** & $5,411 * * *$ & $4,540 * * *$ & $3,423 * * *$ & $3,508 * * *$ & $2,679^{* * *}$ \\
\hline R-square & 0,177 & & 0,278 & & 0,176 & 0,242 & 0,204 & 0,236 & 0,238 \\
\hline $\mathrm{N}$ & 865 & & 865 & & 866 & 872 & 869 & 863 & 851 \\
\hline
\end{tabular}




\begin{tabular}{|c|c|c|c|c|c|c|c|}
\hline $\begin{array}{l}\text { Linear regression models (dep. var. Outward flows per 1,000 } \\
\text { population) }\end{array}$ & $\begin{array}{l}\text { all ages } \\
\text { Coef. }\end{array}$ & $\begin{array}{l}0-14 \text { years } \\
\text { Coef. }\end{array}$ & $\begin{array}{l}15-29 \text { years } \\
\text { Coef. }\end{array}$ & $\begin{array}{l}30-44 \text { years } \\
\text { Coef. }\end{array}$ & $\begin{array}{l}45-59 \text { years } \\
\text { Coef. }\end{array}$ & $\begin{array}{l}60-74 \text { years } \\
\text { Coef. }\end{array}$ & $\begin{array}{l}75+\text { years } \\
\text { Coef. }\end{array}$ \\
\hline \multicolumn{8}{|l|}{ Scenic beauty amenities } \\
\hline \multicolumn{8}{|l|}{ Dominant soil type (ref. cat: Sand) } \\
\hline Marine clay & $0,078 * * *$ & $0,193 * * *$ & 0,002 & $0,099 * * *$ & 0,024 & 0,070 & 0,028 \\
\hline Former peat & 0,022 & 0,059 & $-0,020$ & 0,041 & 0,008 & $0,153 * * *$ & 0,036 \\
\hline \multicolumn{8}{|l|}{ Percentage of housing } \\
\hline built before 1910 & $-0,001$ & $-0,006 * * *$ & 0,001 & $-0,002$ & $-0,003 *$ & 0,001 & 0,001 \\
\hline built between 1910 and 1940 & $0,002 * * *$ & $0,004 * *$ & $0,002 * * *$ & $0,004 * * *$ & $0,003 *$ & 0,001 & 0,001 \\
\hline built between 1945 and 1965 & 0,000 & $-0,001$ & 0,000 & 0,000 & $-0,002$ & 0,001 & 0,003 \\
\hline Number of monuments within village & $-0,002$ & $-0,003$ & $0,002 *$ & $-0,001$ & $-0,001$ & 0,000 & $-0,004$ \\
\hline Distance to protected natural area $(\mathrm{km})$ & 0,000 & 0,000 & $-0,001 *$ & 0,000 & 0,000 & 0,000 & 0,001 \\
\hline Distance to body of water ( $>10$ hectares) & $0,004 * *$ & 0,003 & $0,005 * * *$ & $0,006 * *$ & $-0,001$ & $-0,003$ & 0,001 \\
\hline \multicolumn{8}{|l|}{ Service amenities } \\
\hline \multicolumn{8}{|l|}{ Distance to nearest: $(\mathrm{km})$} \\
\hline Primary school & $0,027 * * *$ & 0,018 & $0,039 * * *$ & $0,036 * * *$ & 0,006 & $0,050 * * *$ & $-0,098 * * *$ \\
\hline Secondary school & $-0,004$ & 0,006 & $-0,010 * * *$ & $-0,003$ & 0,002 & $-0,003$ & $-0,002$ \\
\hline General practitioner & 0,005 & 0,012 & $-0,006$ & 0,008 & 0,012 & 0,010 & $-0,012$ \\
\hline Hospital & $-0,001$ & 0,000 & $-0,003 *$ & 0,000 & 0,002 & 0,001 & 0,002 \\
\hline Supermarket & $0,013 * *$ & 0,020 & 0,009 & 0,012 & 0,009 & $0,036 * * *$ & 0,025 \\
\hline \multicolumn{8}{|l|}{ Quantity (total number within certain distance) } \\
\hline Restaurants within 1 kilometer & 0,000 & 0,002 & 0,006 & 0,008 & 0,006 & $-0,033 * *$ & $-0,040$ \\
\hline Hotels within 20 kilometers & $0,002 * *$ & 0,002 & $0,003 * * *$ & $0,003 * *$ & 0,001 & 0,003 & $0,005 *$ \\
\hline \multicolumn{8}{|l|}{ Accessibility } \\
\hline \multicolumn{8}{|l|}{ Distance to :(km) } \\
\hline Economic center of the Netherlands (Utrecht) & 0,000 & 0,000 & 0,000 & 0,000 & $-0,001$ & 0,001 & 0,000 \\
\hline Nearest urban area $(\mathrm{km})$ & 0,000 & $-0,001$ & 0,001 & $-0,001$ & 0,000 & $-0,002$ & 0,004 \\
\hline Nearest trainstation $(\mathrm{km})$ & 0,001 & 0,004 & $-0,001$ & 0,001 & $0,006 * *$ & $0,005 *$ & 0,003 \\
\hline Nearest main road $(\mathrm{km})$ & $-0,010 *$ & $-0,023 * *$ & 0,003 & $-0,024 * * *$ & $-0,015 *$ & $-0,013$ & $-0,006$ \\
\hline \multicolumn{8}{|l|}{ Jobs } \\
\hline \multicolumn{8}{|l|}{ Number of jobs $(x 1,000)$} \\
\hline Within own municipality & 0,000 & $-0,001$ & 0,000 & 0,000 & 0,000 & 0,000 & 0,002 \\
\hline In municipalities within 15 kilometers & 0,000 & $-0,001 *$ & 0,000 & 0,000 & 0,000 & $-0,001 * *$ & $-0,001$ \\
\hline \multicolumn{8}{|l|}{ Other village characteristics } \\
\hline Total number of households in the village $(x 100)$ & $-0,012 * * *$ & $-0,007$ & $-0,009 * * *$ & $-0,009 * *$ & $-0,011 * * *$ & $-0,027 * * *$ & $-0,035 * * *$ \\
\hline Relative address density & $0,032 * * *$ & $0,050 * * *$ & $0,030 * * *$ & $0,043 * * *$ & $0,033 * *$ & 0,020 & $-0,005$ \\
\hline Population own age category in 1995 (\% of total population) & $\mathrm{x}$ & $-0,018 * * *$ & $-0,010 * * *$ & $-0,011 * * *$ & $0,012 * * *$ & $0,011 * * *$ & 0,015 \\
\hline Owner occupied housing (\% total housing) & $-0,006 * * *$ & $-0,012 * * *$ & $-0,002 * * *$ & $-0,009 * * *$ & $-0,005 * * *$ & 0,001 & $-0,001$ \\
\hline Housing built between 1995 and 2010 (\% of total housing) & 0,001 & $0,005 * *$ & 0,002 & $0,003 *$ & 0,002 & 0,002 & 0,005 \\
\hline Constant & $4,438^{* * *}$ & $4,912 * * *$ & $5,227 * * *$ & $4,782 * * *$ & $3,569 * * *$ & $2,957^{* * *}$ & $4,042 * * *$ \\
\hline R-square & 0,173 & 0,162 & 0,208 & 0,143 & 0,889 & 0,285 & 0,089 \\
\hline $\mathrm{N}$ & 865 & 865 & 866 & 872 & 869 & 863 & 851 \\
\hline
\end{tabular}

